\title{
Subnational Bipartisanship on Climate Change: Evidence from Surveys of Local and State Policymakers
}

\author{
Nathan R. Lee \\ Rochester Institute of Technology \\ nrlcla@ rit.edu
}

\author{
Dominik Stecula \\ Colorado State University \\ dominik.stecula@colostate.edu
}

While the U.S. Congress has repeatedly failed to pass national legislation to address climate change over the years, there has been much more progress among state and local governments. But is this progress on climate change policy at the subnational level merely a reflection of the dominance of the Democratic party in certain regions of the country, or does it reflect successful bipartisan action? In this essay, we present novel evidence from two surveys of subnational policymakers, conducted in 2015 and 2017, to demonstrate that there is widespread bipartisan agreement among Republican and Democrat policymakers at the subnational level about (1) the existence of global warming and (2) what to do about it. Specifically, a majority in both parties believe global warming is happening and support the use of renewable energy mandates-rather than cap-and-trade, carbon tax, or emissions standards - to address the problem.

This version: October 31, 2020 


\section{Introduction}

Since global warming became a topic of discussion in Washington D.C. in the late 1980s, the U.S. Congress has repeatedly failed to pass national legislation to address the issue (Skocpol 2013). Meanwhile, the state of play on climate change in subnational politics looks very different: twentynine states have passed renewable energy mandates, nine states have passed cap-and-trade programs, and 446 local governments have committed to upholding the Paris Climate Accord. ${ }^{1}$ What does a closer look at the subnational politics of climate change tell us about the prospects for national legislation? But is this progress on climate change policy at the subnational level merely a reflection of the dominance of the Democratic party in certain regions of the country, or does it reflect successful bipartisan action?

In this essay, we present novel evidence from two surveys of subnational policymakers, conducted in 2015 and 2017, respectively, to demonstrate that there is widespread bipartisan agreement among Republican and Democrat policymakers at the subnational level about (1) the existence of global warming and (2) what to do about it. Specifically, a majority in both parties believe global warming is happening and support the use of renewable energy mandates - rather than cap-andtrade, carbon tax, or emissions standards - to address the problem.

These findings-which correspond well with the observed patterns of subnational policy adoption - may point to a more bipartisan path forward on climate legislation at the national level.

\section{Investigating Subnational Climate Change Politics}

Can the progress of state and local governments in adopting climate change policies teach us anything about a path forward for national legislation? One possibility could be that the adoption of subnational policies to address climate change merely reflects the dominance of the Democratic party in certain regions of the country. If this were the case, this would offer few insights for national politics. On the other hand, subnational progress on climate change may reflect some degree of underlying bipartisanship. To the extent that this is the case, then proponents of climate change action would be wise to take note.

Existing studies examining subnational variation in climate policy adoption suggest a range of explanations. ${ }^{2}$ Among them, one can find clear evidence in favor of the idea that Democratic Party control is associated with more adoption of climate policies (Rabe 2004; Huang et al. 2007; Lyon and Yin 2010; Yi and Feiock 2014). But there are also many examples of climate policy adoption in localities or states that are not controlled by the Democratic Party. In fact, a majority of the twenty-nine states that adopted a renewable portfolio standard did so under the control of a Republican governor (Lee 2020). At the city level, Boussallis and co-authors (2018) find only mixed evidence of Democratic control being associated with local government behavior on climate change, while Hughes (2019) finds no evidence of partisanship mattering.

\footnotetext{
${ }^{1}$ State-by-state data on renewable energy policies can be found at dsireusa.org/and city-by-city data on climate actions can be found at climatemayors.org/actions/. A map of which states have adopted renewable energy mandates, or "renewable portfolio standards," is shown in Figure A1.

${ }^{2}$ These explanations include elite partisan politics (Rabe 2004; Huang et al. 2007; Lyon and Yin 2010; Yi and Feiock 2014), but also competing interest groups (Carley 2011, Cheon and Urpelainnen 2013; Aklin and Urpelainen 2013; Stokes 2015; Meckling et al. 2015) and the organization of the energy industry (Lee 2020).
} 
With respect to the question at hand, these studies can provide only limited insights. That is because the unit of analyses in the studies above are actions of an entire governments. Consequently, it is difficult to infer much about the distribution of policy preferences by party across individual policymakers. In this study, we seek to answer this question directly by leveraging survey data of subnational policymakers. While self-reported data presents its own limitations, the upside is that one can explore individual decision-makers. However, this approach has rarely been pursued due to the difficulties in conducting policymaker surveys in the United States.,

\title{
National Survey of Subnational Policymakers
}

To fill this gap, we utilize two separate surveys conducted by CivicPulse, ${ }^{5}$ a nonprofit research organization which began running surveys of subnational public officials in 2015. The two surveys - conducted in 2015 and 2017, respectively-were implemented online via email using random samples of officials from a comprehensive list of elected officials at the township, municipality, county, and state legislative level. In the 2015 survey, 631 local policymakers and 82 state legislators (or their legislative staffers) responded. In 2017, the sample was comprised of 659 local policymakers and 109 state legislators/staffers. Further details of the survey samples are provided in the Appendix (Tables A1-A2). ${ }^{6}$

To characterize the geographic representativeness of the surveys, we geocoded all respondents using the FIPS system and subsequently match these respondents to the U.S. Census and the 2016 presidential election results by locality and state legislative district (Tables A5 - A8). We generate survey weights using a raking methodology developed for the American National Election Study (DeBell and Krosnick 2009). All results below are reported with survey weights, but the results are not sensitive to these weights.

\section{Assessing Climate Change Beliefs and Policy Preferences}

The first of the two survey questions we use in this study was asked in a CivicPulse survey conducted in February 2017. This survey question assesses belief in whether global warming is occurring (see below).

\begin{abstract}
You may have heard about the idea that the world's temperature may have been going up slowly over the past 100 years. What is your personal opinion on this? Do you think this has probably been happening, or do you think it probably hasn't been happening?
\end{abstract}

\footnotetext{
3 Two notable exceptions, which draw on past subnational policymaker surveys on climate change, are Gerber (2012) and Einstein et al. (2020).

${ }^{4}$ Additional approaches have been to analyze press releases. An alternative approach is to examine roll-call data when specific climate policies come to the floor in a state or local legislature.

${ }^{5}$ www.civicpulse.org

${ }^{6}$ The relative balance of local versus state officials in our samples reflects the sheer number of local policymakers: an estimated 200,000 local policymakers work across the nearly forty thousand local governments in the United States, compared with approximately 16,000 state legislators and legislative staffers. In other words, each of our survey samples includes roughly $0.3 \%$ of the total population of local policymakers (631 - 659 respondents), and roughly $0.5 \%$ of the total population of state policymakers and their staffers ( $82-109$ respondents).
} 
It is important to note that some debate exists concerning whether the use of "global warming" versus "climate change" significantly impacts the response (Villar \& Krosnick, 2011, Motta et al 2019). We chose the wording above because it is the standard way the American National Election Study surveys the mass public on the question of climate change belief.

The second question included in this study was asked in a CivicPulse survey conducted in August 2015. The question offers policymakers four standard policy interventions to reduce greenhouse gas emissions in the power sector in the United States (see below).

Suppose the United States decides to reduce its greenhouse gas emissions through government action. If you had to choose from the following list, which policy would you select? \{Carbon tax, Cap-and-trade, Emissions standards for power plants, Renewable energy mandate\}

The choice not to offer a fifth "none of the above" option is intentional, though it entails a tradeoff. By doing so, the response pattern provides the opportunity to identify which of the four policies would have the most bipartisan support relative to its alternatives. On the other hand, it precludes the possibility of attempting to infer what a given policymaker's absolute preferences are (i.e., would they vote up or down on a given policy).

\section{Subnational Bipartisanship on Climate Change}

\section{Belief in existence}

Beginning with an analysis of the climate change belief question, we observe modest polarization between parties at both levels of government. ${ }^{7}$ This polarization is moderated by the very high overall baseline of belief. In local government, $100 \%$ of Democrats believe global warming is happening, compared to $76 \%$ of Republicans. In state government, the percentages are $100 \%$ and $83 \%$ for Democrats and Republicans, respectively. Put another way: notwithstanding a significant degree of polarization, a large majority of both parties in both local and state government believe in the existence of climate change.

\footnotetext{
${ }^{7}$ Differences between parties are statistically significant (Local: chi2 $=57.7, \mathrm{p}<0.01$; State: chi2 $=8.3, \mathrm{p}<0.01$ ). Results are weighted.
} 

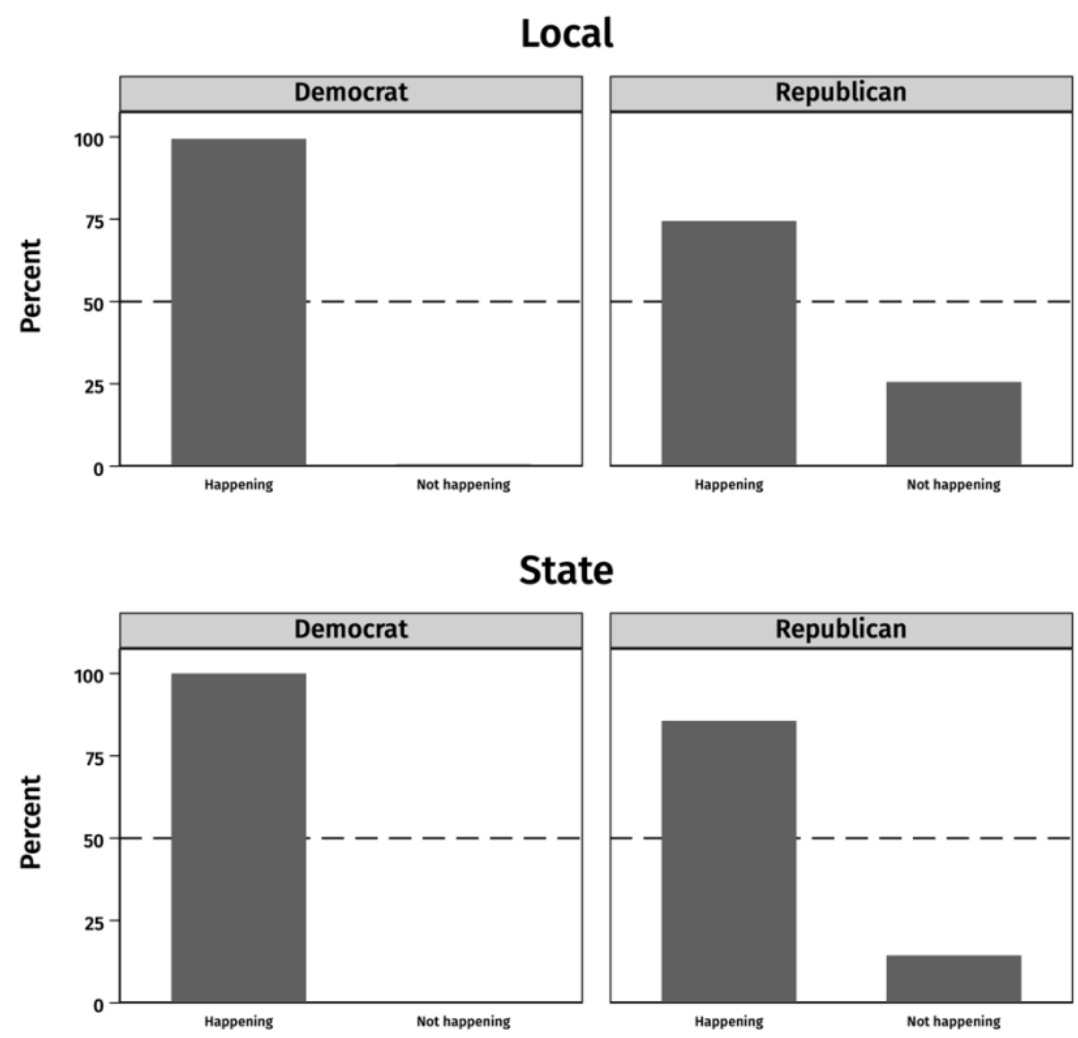

Figure 1. Belief in climate change existence, by party affiliation and level of government.

\section{Policy preference}

Turning to climate policy preferences, we find a clear pattern across both party and level of government: the renewable energy mandate is the most popular choice. This is especially true for Democrats in local government and Republicans in state government, but it is consistent in all four quadrants. ${ }^{8}$ No other policy comes nearly as close to earning bipartisan support. We provide more breakdowns of these results in the Appendix (Tables A2 - A4).

${ }^{8}$ Differences between parties are statistically significant at the local but not the state level (Local: chi2 $=30.3$, $\mathrm{p}<0.01$; State: chi2 $=1.3, \mathrm{p}=0.73$ ). Results are weighted. 

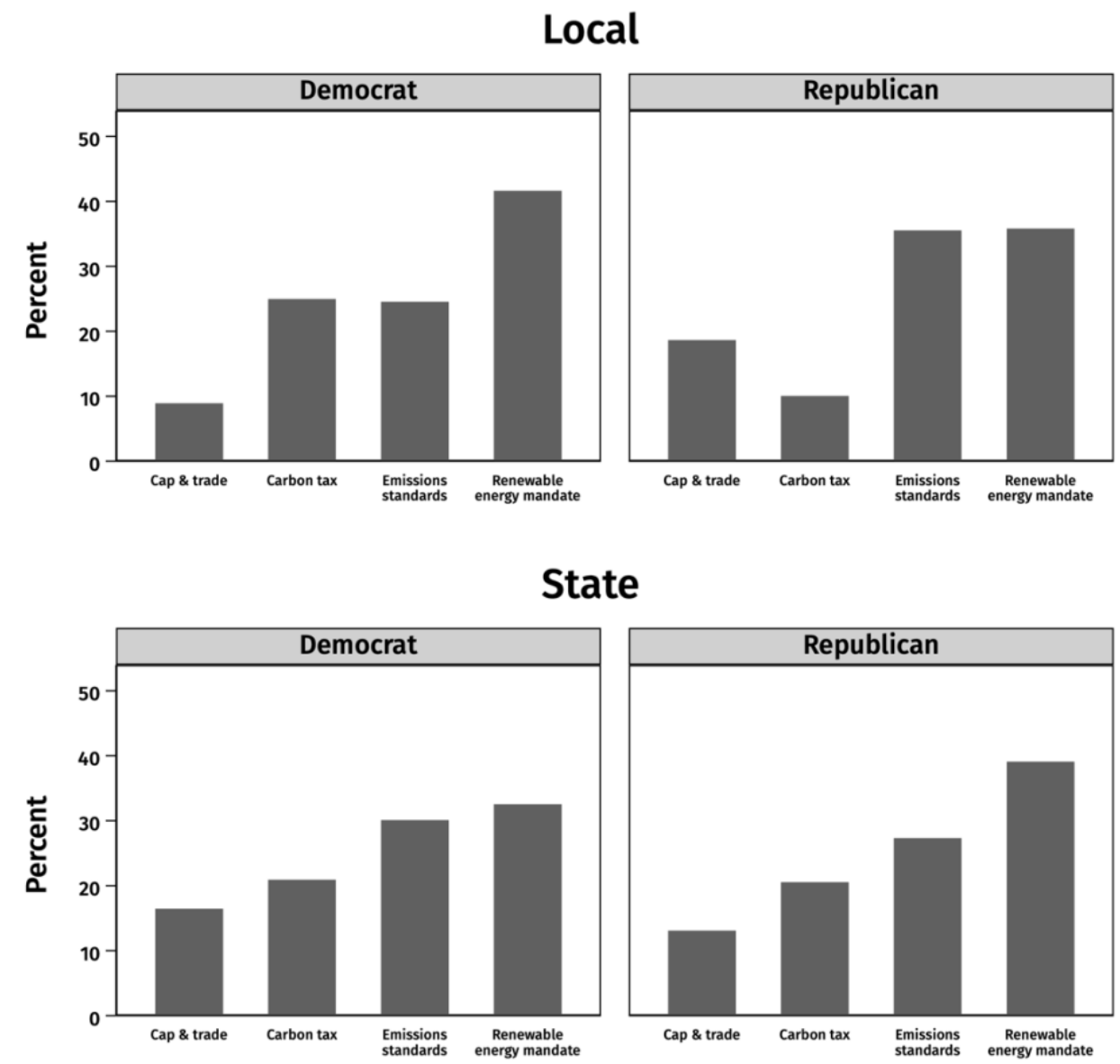

Figure 2. Climate change policy preference, by party affiliation and level of government.

\section{Discussion and Conclusion}

These findings suggest a more bipartisan picture of climate change politics at the subnational level than what we observe nationally. While noting a moderate degree of polarization, we nonetheless demonstrate that most Republican lawmakers at the subnational level-like nearly all Democrats - agree that climate change has been happening. More importantly, Republicans and Democrats generally align on the type of policy response to climate change, namely, the renewable energy mandate. These findings are not limited to local officials alone, they hold for our smaller sample of state legislators and legislative staffers, as we highlight throughout the paper.

This is consistent with what we see in real-world legislative behavior: nearly thirty states have adopted the renewable energy mandate, more than the number of states that have adopted a capand-trade program, a carbon tax, or a carbon emissions standard combined. Despite environmental economists' preferences for carbon tax and cap-and-trade as the most efficient solutions to carbon pollution, these results clearly suggest that the most politically feasible solution is the renewable energy mandate. This finding is also consistent with surveys of the general public (Krosnick and MacInnis 2013; Stokes and Warshaw 2017). 
There are at least four limitations to this study to address when considering its real-world policy implications. The first is that this study draws on surveys from the past (2015-2017). However, this caveat, in our view, does not derail the applicability of these findings. This is because studies of public opinion about different climate policy preferences demonstrate enduring reasons why a renewable energy mandate would be psychologically more attractive in comparison to its alternatives, namely that it emphasizes the benefit (renewable energy) rather than the financial cost (Krosnick and MacInnis 2013; Ansolabehere and Konisky 2014).

The second is that these questions do not allow us to measure the full range of beliefs and preferences that might influence a policymaker's behavior (Jenkins-Smith et al. 2018). For example, the belief in the existence of global warming does not necessarily have the same policy implications that the belief in anthropogenic global warming does. We believe this concern is somewhat mitigated since we also ask policy preferences alongside beliefs, but the fact remains that additional survey data would be needed to flesh out the full constellation of policymakers' beliefs and preferences on climate change.

The third is that these surveys are not perfectly representative. CivicPulse modestly oversamples municipalities, counties, and state legislative districts that are more populous, more urban, more liberal, and more educated. Further information on representativeness is provided in the appendix (Tables A4-A8). To address this, we constructed survey weights using these Census-area characteristics upon which the sample is biased and demonstrate that the findings are insensitive to inclusion or exclusion of weights. Furthermore, the findings are consistent when looking within each Census region (Table A4). Nonetheless, the limitations in representativeness of the sample are important to keep in mind.

Finally, it is worth asking to what extent these findings are applicable to national policymakers. One concern is that subnational policymakers may not exhibit the same kind of polarization that is demonstrable among national policymakers. On this count, there is a growing amount of evidence that subnational policymakers are, at least directionally, polarized along national party lines (Einstein and Glick 2018; Hopkins 2018; Caughey et al. 2017; Gerber and Hopkins 2011; Lee et al. nd). Consequently, the question seems to be one of degrees, rather than kind. Moreover, even if Republicans in Congress were less supportive overall in addressing climate change than their counterparts in subnational government, our finding about the relative preferences between policy choices seems likely to hold.

Taken together, these findings - along with the subnational legislative track record on climate change - suggest closer attention to local and state government is warranted: they may show the way toward the best possibility of finally achieving national bipartisan climate change legislation in the United States. 


\section{References}

Aklin M, Urpelainen J (2013) Political competition, path dependence, and the strategy of sustainable energy transitions. Am. J. Polit. Sci. 57 (3), 643-658.

http://dx.doi.org/10.1111/ajps.12002.

Ansolabehere S, Konisky DM (2014) Cheap and clean: How Americans think about energy in the age of global warming. MIT Press.

Bolsen T, Druckman JN, Cook FL (2015) Citizens', Scientists', and Policy Advisors' Beliefs about Global Warming. The ANNALS of the American Academy of Political and Social Science, 658(1), 271-295. https://doi.org/10.1177/0002716214558393

Boussalis C, Coan TG, Holman MR (2018) Climate change communication from cities in the USA. Climatic Change 149(2): 173-187. DOI: 10.1007/s 10584-018-2223-1.

Carley S, (2011) The era of state energy policy innovation: A review of policy instruments. Rev. Policy Res.

Caughey D, Yiqing X, Warshaw C (2017) Incremental Democracy: The Policy Effects of Partisan Control of State Government. The Journal of Politics 79 (4):1342-1358.

Cheon A, Urpelainen J (2013) How do competing interest groups influence environmental policy? The case of renewable electricity in industrialized democracies, 1989-2007. Polit. Stud. (ISSN: 00323217) 61 (4), 874-897. http: //dx.doi.org/10.1111/14679248.12006.

DeBell M, Krosnick JA (2009) Computing Weights for American National Election Study Survey Data. ANES Technical Report series, no. nes012427. Ann Arbor, MI, and Palo Alto, CA: American National Election Studies. http://www.electionstudies.org/resources/papers/nes012427.pdf

Einstein KL, Glick DM (2018) Mayors, Partisanship, and Redistribution: Evidence Directly from US Mayors. Urban Affairs Review 54 (1): 74-106.

Einstein KL, Glick DM, Palmer M (2020) Can Mayors Lead on Climate Change? Evidence from Six Years of Surveys. The Forum, 18(1), 71-86. https://doi.org/10.1515/for-2020-1004

Fielding KS, Head BW, Laffan W, Western M, Hoegh-Guldberg O (2012) Australian politicians' beliefs about climate change: Political partisanship and political ideology. Environmental Politics, 21(5), 712-733. https://doi.org/10.1080/09644016.2012.698887

Gerber ER (2013) Partisanship and Local Climate Policy. Cityscape, 107-124. https://www.jstor.org/stable/41958959?seq=1 
Gerber ER, Hopkins DJ (2011) When Mayors Matter: Estimating the Impact of Mayoral Partisanship on City Policy. American Journal of Political Science 55(2): 326-339.

Hopkins DJ (2018) The Increasingly United States: How and Why American Political Behavior Nationalized. University of Chicago Press.

Huang MY, Alavalapati JRR, Carter DR, Langholtz MH (2007) Is the choice of renewable portfolio standards random? Energy Policy.

Hughes S (2019) Repowering Cities: Governing Climate Change Mitigation in New York City, Los Angeles, and Toronto. Illustrated edition. Ithaca: Cornell University Press.

Jenkins-Smith HC, Nohrstedt D, Weible CM, et al. (2018) The Advocacy Coalition Framework: An Overview of the Research Program. In: Weible CM and Sabatier P (eds) Theories of the Policy Process. 4th ed. New York: Routledge, pp. 135-171. DOI: 10.4324/9780429494284-5.

Krosnick JA, MacInnis B (2013) Does the American public support legislation to reduce greenhouse gas emissions? Daedalus 142.1, 26-39.

Lee NR (2020) When Competition Plays Clean: How Electricity Market Liberalization Facilitated State-level Climate Policies In The United States. Energy Policy.

Lee NR, Landgrave M, Bansak K Polarization in Subnational Government: Evidence from Surveys of Township, Municipal, County, and State Policymakers. Working Paper. URL: dropbox.com/s/3xgtil4lhmc9uv8/Subnational_polarization.pdf?dl=0

Lyon TP, Yin H (2010) Why do states adopt renewable portfolio standards?: An empirical investigation. Energy J. 31 (3), 133-157.

Meckling J, Kelsey N, Biber E, Zysman J (2015) Winning coalitions for climate policy. Science.

Motta M, Chapman D, Stecula DA, Haglin K (2019) An experimental examination of measurement disparities in public climate change beliefs. Climatic Change, 154(1), 3747. https://doi.org/10.1007/s10584-019-02406-9

Rabe BG (2004) Statehouse and Greenhouse: The Emerging Politics of American Climate Change Policy. Brookings Institution Press.

Skocpol T (2013) Naming the Problem: What It Will Take to Counter Extremism and Engage Americans in the Fight against Global Warming Source: https://climateaccess.org/resource/naming-problem-what-it-will-take-counter-extremismand-engage-americans-fight-against 
Stokes LC (2015) Power Politics: Renewable Energy Policy Change in US States. Diss. Massachusetts Institute of Technology.

Stokes LC, Warshaw C (2017). Renewable energy policy design and framing influence public support in the United States. Nat Energy 2, 17107. https://doi.org/10.1038/nenergy.2017.107

Sundblad EL, Biel A, Gärling T (2009) Knowledge and Confidence in Knowledge About Climate Change Among Experts, Journalists, Politicians, and Laypersons. Environment and Behavior, 41(2), 281-302. https://doi.org/10.1177/0013916508314998

Villar A, Krosnick JA (2011) Global warming vs. climate change, taxes vs. prices: does word choice matter? Climatic Change 105(1):11-12.

Yi H, Feiock RC (2014) Renewable energy politics: policy typologies, policy tools, and state deployment of renewables. Policy Stud. J. 


\section{Appendix for Subnational Bipartisanship on Climate Change: Evidence from Surveys of Local and State Policymakers}

Table A1. Survey respondents by level.

\begin{tabular}{lrr}
\hline & 2017 Survey & 2015 Survey \\
\hline Township (Subcounty) & $52(7 \%)$ & $73(10 \%)$ \\
Municipality (Subcounty) & $352(46 \%)$ & $357(50 \%)$ \\
County & $255(33 \%)$ & $201(28 \%)$ \\
State & $109(14 \%)$ & $82(12 \%)$ \\
\hline Total & $\mathbf{7 6 8 ( 1 0 0 \% )}$ & $\mathbf{7 1 3 ( 1 0 0 \% )}$ \\
\hline
\end{tabular}

Table A2. Responses by party, local officials.

\begin{tabular}{c|ccc|ccccc}
\hline & \multicolumn{3}{|c|}{ Climate belief (\%) } & \multicolumn{4}{c}{ Climate policy (\%) } \\
\hline & $\mathbf{n}$ & Happening & $\begin{array}{c}\text { Not } \\
\text { happening }\end{array}$ & $\mathbf{n}$ & $\begin{array}{c}\text { Carbon } \\
\text { tax }\end{array}$ & $\begin{array}{c}\text { Cap-n- } \\
\text { trade }\end{array}$ & $\begin{array}{c}\text { Emissions } \\
\text { standard }\end{array}$ & $\begin{array}{c}\text { Renewable } \\
\text { mandate }\end{array}$ \\
\hline Democrat & 208 & 99.6 & 0.4 & 216 & 28 & 12 & 21 & 39 \\
Republican & 250 & 75 & 25 & 277 & 10 & 15 & 36 & 39 \\
Indep./Other & 171 & 96 & 4 & 158 & 18 & 9 & 32 & 41 \\
\hline
\end{tabular}

Table A3. Responses by party, state officials.

\begin{tabular}{c|ccc|ccccc}
\hline & \multicolumn{3}{|c|}{ Climate belief (\%) } & \multicolumn{4}{c}{ Climate policy (\%) } \\
\hline & $\mathbf{n}$ & Happening & $\begin{array}{c}\text { Not } \\
\text { happening }\end{array}$ & $\mathbf{n}$ & $\begin{array}{c}\text { Carbon } \\
\text { tax }\end{array}$ & $\begin{array}{c}\text { Cap-n- } \\
\text { trade }\end{array}$ & $\begin{array}{c}\text { Emissions } \\
\text { standard }\end{array}$ & $\begin{array}{c}\text { Renewable } \\
\text { mandate }\end{array}$ \\
\hline State Respondents & 82 & 93 & 7 & 108 & 21 & 19 & 27 & 33 \\
Democrats & 45 & 100 & 0 & 51 & 24 & 18 & 27 & 31 \\
Republicans & 29 & 83 & 17 & 32 & 16 & 12 & 31 & 41 \\
Indep./Other & 8 & 88 & 12 & 25 & 24 & 28 & 20 & 28 \\
\hline
\end{tabular}

Table A4. Survey responses by region.

\begin{tabular}{c|ccc|ccccc}
\hline & \multicolumn{3}{|c|}{ Climate belief (\%) } & \multicolumn{4}{c}{ Climate policy (\%) } \\
\hline & $\mathbf{n}$ & Happening & Not happening & $\mathbf{n}$ & $\begin{array}{c}\text { Carbon } \\
\text { tax }\end{array}$ & $\begin{array}{c}\text { Cap-n- } \\
\text { trade }\end{array}$ & $\begin{array}{c}\text { Emissions } \\
\text { standard }\end{array}$ & $\begin{array}{c}\text { Renewable } \\
\text { mandate }\end{array}$ \\
\hline Midwest & 226 & 87 & 13 & 251 & 16 & 14 & 28 & 42 \\
Northeast & 153 & 93 & 7 & 145 & 23 & 12 & 32 & 33 \\
South & 158 & 85 & 15 & 185 & 10 & 9 & 33 & 48 \\
West & 169 & 91 & 9 & 171 & 25 & 18 & 27 & 30 \\
\hline
\end{tabular}

Table A5. Sample Representativeness by Urbanicity, Median Locality/District in Sample vs. USA. Urbanicity is measured by the percent of residents in each locality (or state legislative district) living in an urban area (US Census).

\begin{tabular}{|c|r|r|r|}
\hline Survey & Level & Sample Median & USA Median \\
\hline \multirow{3}{*}{2015} & Subcounty & 1.00 & 0.72 \\
\cline { 2 - 4 } & County & 0.55 & 0.40 \\
\cline { 2 - 4 } & State & 0.92 & 0.89 \\
\hline \multirow{3}{*}{2017} & Subcounty & 0.99 & 0.72 \\
\cline { 2 - 4 } & County & 0.54 & 0.40 \\
\cline { 2 - 4 } & State & 0.92 & 0.89 \\
\hline
\end{tabular}


Table A6. Sample Representativeness by Education Level, Median Locality/District in Sample vs. USA. Education level is measured by the percent of residents in each locality (or state legislative district) living in an urban area (US Census).

\begin{tabular}{|c|l|r|r|}
\hline \multirow{3}{*}{ Survey } & \multicolumn{1}{|c|}{ Level } & Sample Median & \multicolumn{1}{c|}{ USA Median } \\
\hline \multirow{3}{*}{2015} & Subcounty & 0.32 & 0.21 \\
\cline { 2 - 4 } & County & 0.23 & 0.19 \\
\cline { 2 - 4 } & State & 0.29 & 0.26 \\
\hline \multirow{3}{*}{2017} & Subcounty & 0.32 & 0.21 \\
\cline { 2 - 4 } & County & 0.23 & 0.19 \\
\cline { 2 - 4 } & State & 0.30 & 0.26 \\
\hline
\end{tabular}

Table A7. Sample Representativeness by Population Size, Median Locality/District in Sample vs. USA.

\begin{tabular}{|c|l|r|r|}
\hline \multirow{3}{*}{ Survey } & Level & Sample Median & \multicolumn{1}{c|}{ USA Median } \\
\hline \multirow{3}{*}{2015} & Subcounty & 28515 & 3314 \\
\cline { 2 - 4 } & County & 57934 & 25763 \\
\cline { 2 - 4 } & State & 65342 & 46252 \\
\hline \multirow{3}{*}{2017} & Subcounty & 25488 & 3314 \\
\cline { 2 - 4 } & County & 58178 & 25763 \\
\cline { 2 - 4 } & State & 54280 & 46252 \\
\hline
\end{tabular}

Table A8. Sample Representativeness by 2016 Trump Vote Share, Median Locality/District in Sample vs. USA. Median 2016 vote share for Trump is shown for each type of area. County-level data was used for sub-county localities.

\begin{tabular}{|r|l|r|r|}
\hline \multicolumn{1}{|c|}{ Survey } & Level & \multicolumn{1}{c|}{ Sample Median } & \multicolumn{1}{c|}{ USA Median } \\
\hline 2015 & Subcounty & 0.45 & 0.58 \\
\hline 2015 & County & 0.58 & 0.67 \\
\hline 2015 & State & 0.41 & 0.51 \\
\hline 2017 & Subcounty & 0.45 & 0.58 \\
\hline 2017 & County & 0.60 & 0.67 \\
\hline 2017 & State & 0.37 & 0.51 \\
\hline
\end{tabular}


Figure A1. US states who have adopted a renewable energy mandate. This map shows which U.S. states have adopted a renewable energy mandate, or "renewable portfolio standard," since 1996. Two states (Kansas and West Virginia) have since repealed these policies.

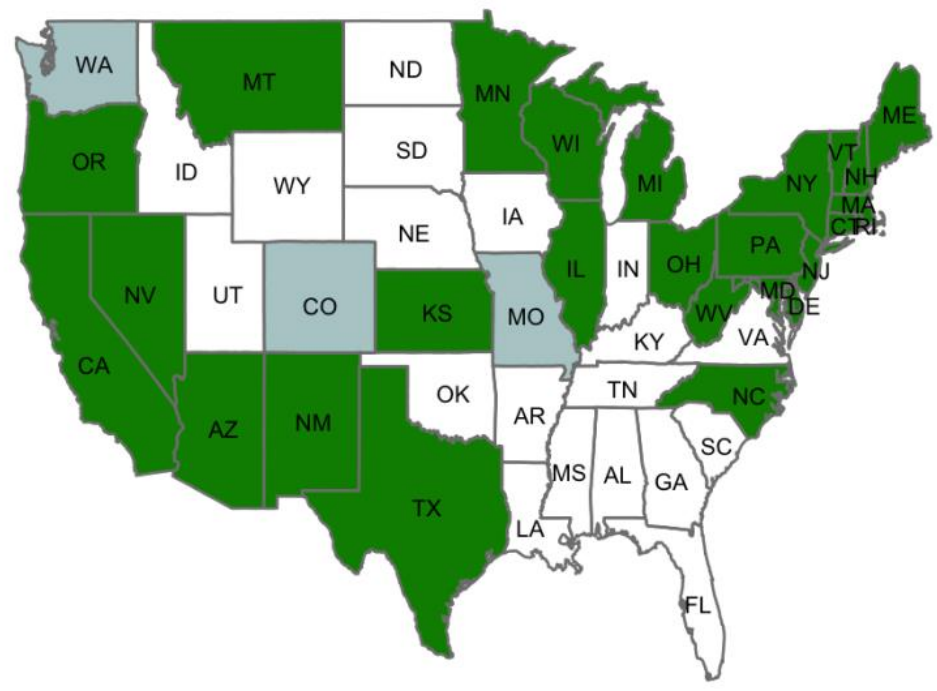

by legislation

by referendum

Figure A2. Geographic distribution of survey respondents (2015 survey).

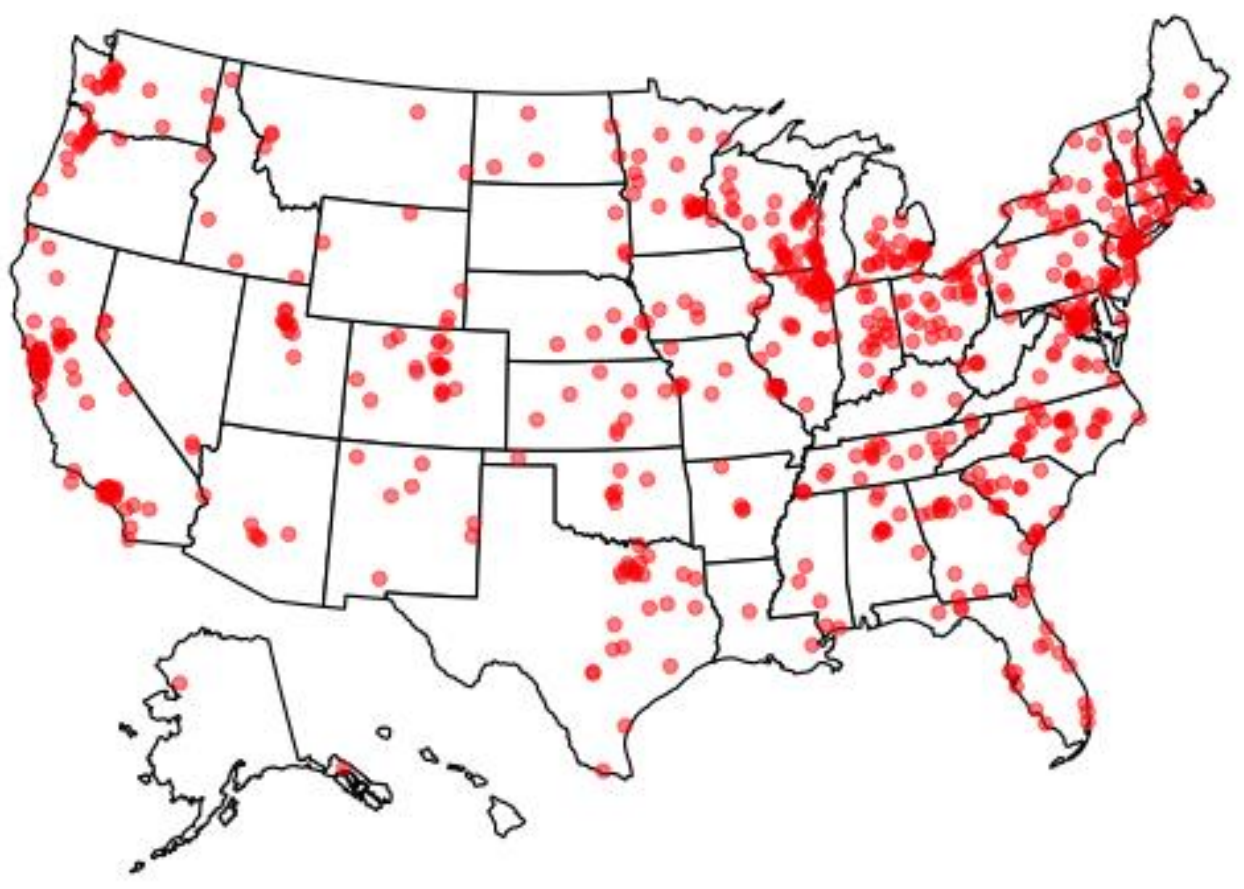


Figure A3. Geographic distribution of survey respondents (2017 survey).

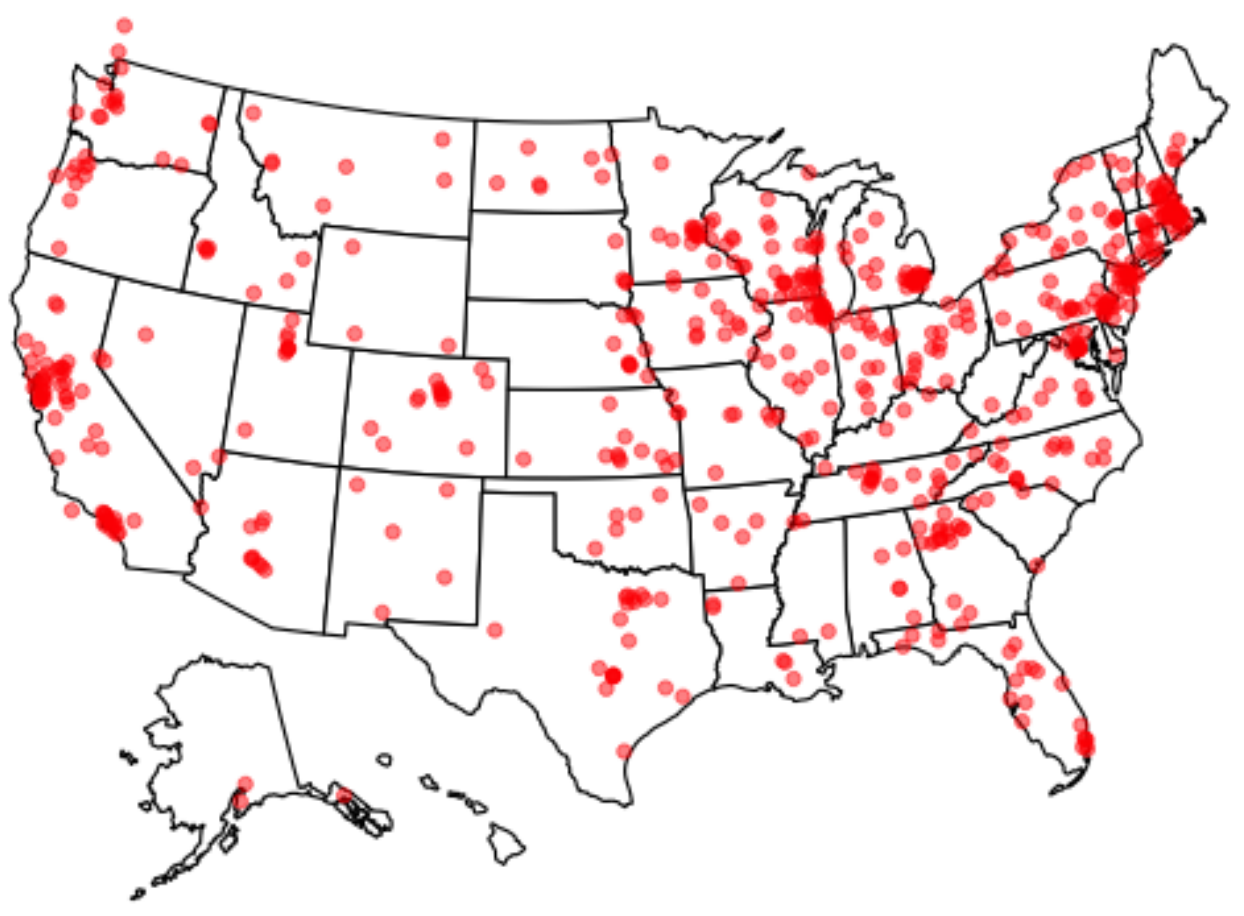

